\title{
THE INFLUENCE OF QUALITY OF WORK LIFE ON WORK PERFORMANCE
}

\author{
Raluca RUSU \\ "Nicolae Bălcescu" Land Forces Academy, Sibiu, Romania \\ rbalasoiu@yahoo.com
}

\begin{abstract}
In the dynamic time in which we live, job and life satisfaction have emerged as major issues in the field of organizational behavior. Considering that the goal of every organization is to prosper and maintain its competitiveness, employers are forced to pay attention to employees' job performance, which is positively related to the quality of their working life. This could be attributed to the fact that employees who attain high levels of job and life satisfaction tend to be highly motivated and work more efficiently. Consequently, starting from a secondary analysis based on data provided by the European Working Condition Survey, the present paper aims at drawing a picture of the way employed population in Romania relates to different quality components of work life.
\end{abstract}

Keywords: quality of work life, performance, work satisfaction

\section{Introduction}

One of the main capabilities of organizations is to provide an environment favorable to talent development, known in the literature as an environment that supports quality of work life [1]. According to Straw and Heckscher (1984), the quality of work life expresses a philosophy, a set of principles that highlight the fact that people represent the most important resource in an organization and deserve to be treated with dignity and respect [2]. Some authors define the quality of work life as the physical, mental and emotional well-being of employees at work.

Although most organizations today consider that the quality of work life is extremely important, most often organizational strategies do not reflect it. This can affect employees' professional satisfaction and encourage withdrawal behaviors (absenteeism and / or resignation).

Therefore, Wyatt and Wah (2001) state that "improving conditions at work ... can lead to greater performance, driven by the individuals' loyalty, as well as to a better quality of life in society. "[4]

\section{Conceptualization and measurement of quality of work life}

Several ways to define and operationalize the concept are to be found in literature. They reflect various attempts to find how the quality of working life can be measured, evaluated and then improved. The attempts of clarification and measurement have divided the indicators of the quality of working life into intrinsic and extrinsic, or objective and subjective, without agreeing, however, on a single definition. Among the items accepted today we find the working conditions, the professional relations, the opportunity of 
professional development, the protection from social risks and accidents, and other aspects that contribute to the employee's professional satisfaction and wellbeing. [5]

Walton's model (1975) has remained a reference point in terms of measuring the quality of working life, even if organizational realities have changed since it was built. The author believes that, by meeting the employees' most important needs, the quality of working life can be highly improved. In his view, the concept has to be interpreted through eight dimensions, namely: adequate and fair compensation; safe and healthy working environment; opportunities for career development and safety; development of human capabilities; full living space (a balance between time spent to work and time devoted to family); social integration in the organization; constitutionalism in the work organization, and, last but not least, social relevance of working life [6].

On the other side, Lewis et al (2001) identify other dimensions that can influence the quality of working life: fairness ( perceived organizational justice), supervision, organizational decisions, professionalism, education, professional feed-back, promotion opportunities, correct wages, positive relationships, autonomy and professional recognition.[7]

Hereafter, we briefly explain the most important indicators used in the operationalization of the "quality of work life' concept.

Working conditions refer to the physical environment supposed to facilitate the professional activity and not affect the employee's health. The health status has a significant influence on the work performance and motivation, and can lead to job loss, decreased productivity and increased staff turnover. Therefore, the employer and the social policies provide some protective measures: free health monitoring services, reduction of the working time duration, alternating with mandatory rest periods, etc.
Professional relations concern both vertical and horizontal work relationships. The latter refers to peer-collaboration relationships that help building a positive organizational climate. The quality of the manager's leadership style has a major impact on professional relationships aspects related to subordinates' discriminatory treatment, equal access to vocational training and promotion, etc. Professional relations also refer to the employees' possibility to express their views and participate in decision making. The latter aspect particularly leads to greater organizational commitment and job satisfaction, because it is only this way that employees understand the importance and responsibility of their work, and their creativity and motivation for professional development are stimulated [8].

Professional development means to keep employees informed on the changes in their professional field, and adapt their professional competencies to them. It is about having the opportunity to participate in courses and trainings designed to develop employees' interest and job satisfaction through diversification of work, promotion prospects, access to new perspectives, work utility awareness. [9] They can have the role to reward and also to protect the employees against the risk of unemployment due to professional obsolescence.

Other aspects that contribute to defining the quality of working life are the rates of pay, the working time, the protection against social risks (accidents, illness, incapacity to exercise the profession due to age, to temporary suspension or permanent termination of employment), provision of leisure and nursery services. These are factors that boost employees' happiness, and enhance their working capacity, aiming at the same time to provide a healthy work-life balance.

Recent years have witnessed several attempts to measure the quality of 
working life mentioned above. In order to build social policies appropriate to each country, and, generally, to improve the quality of life of individuals, in Europe there is the European Working Condition Surveys. Since its launch in 1990, it has carried out a survey every five years. The European Working Condition Surveys comprises a section that measures the quality of working life in the European countries, including Romania. The dimensions taken into consideration are: cognitive factors, health and well-being, job context, job fulfilment, physical factors, psychosocial factors, skills, training and career prospects, social relationships, violence, harassment and discrimination, work intensity organization, work-life balance, financial security and working time duration .

Hereafter, we will analyze the quality of working life in Romania, starting with the above-mentioned dimensions. The method used will be the secondary analysis on data provided on www.eurofound. europa.eu. For each dimension, we have considered a number of indicators relevant to our theme.

\section{Analysis of the quality of working life in Romania}

Within the Cognitive factors dimension, we chose four relevant indicators concerning the quality of working life among Romanians, namely: working with computers, using Internet or email, learning things and rotating tasks that require special skills. (see Table 3)

Most of the answers show that the technological infrastructure is poorer in Romania compared to the European average, which probably causes dissatisfaction with the working conditions necessary for carrying out professional duties.

Most Romanians consider that their work gives them the opportunity to learn new things, which can increase intrinsic motivation, but the average still remains below the EU average. At the question, "Does your job involve rotation of tasks requiring different skills?" the majority said "no", which shows that there is no concern in the organization of work on the principle of job enrichment.

\section{Health and well-being dimension}

Within this dimension, we measured the following indicators: informed about health and safety risk related to job, and work affecting health. As one can see in Table 1, the majority had been informed about the possible risks of their work, and also $58.7 \%$ of them consider that their work does not affect their health. These answers indicate that in the companies in Romania there are concerns for employees' health and wellbeing.

\section{Job context dimension}

Within this dimension, we asked only one fundamental question, namely: "Has your salary or income changed in the past year?" $56,9 \%$ of the respondents indicated no change, $32,8 \%$ said that their salaries had decreased, and only $10,3 \%$ had had a pay raise. One explanation might be related to the fact that the data collection (after 2010) coincided with the crisis in Romania, and even with decrease of some professionals' wages.

\section{Job fulfilment dimension (see Tabel 2 )}

The majority of the respondents to our survey $(89.1 \%)$ stated that they always, or most of the times, feel they do useful work, $75.4 \%$ are very satisfied, or satisfied with the conditions at their workplace. 75.2 agree with the statement that they have good friends among colleagues at work, regardless of age, and $48.8 \%$ agree that the organization provides an environment based on performance.

As for the Skills, training and career prospects dimension, only $18.2 \%$ attended training courses paid by the employer compared to $34 \%$ at European level. The European countries with lower percentages than ours in terms of investment in human resource 
development are: Bulgaria, Greece, Montenegro and Kosovo. A large number of respondents $(62.5 \%)$ believe that the workplace does not offer them great opportunities to advance in their career. (see Table 4)

\section{Social relationship}

We can say that the Romanian organizational climate is a supportive one, given that $76.8 \%$ of respondents believe that they have colleagues on whom they can rely, and $71 \%$ have supportive managers. As for their participation in decision-making, $65.4 \%$ said they were encouraged to express their opinions and offer solutions to problems.

\section{Violence, harassment and discrimination}

The answers to the questions within this dimension show that Romanian organizational environment is not characterized by phenomena such as mobbing or bullying, making people feel safe at the workplace, which greatly contributes to the improvement of the quality of work life. Thus, $95.6 \%$ said that they had never been subject to discrimination, a similar percentage also representing the answers given by female respondents (94.4\%). At the question "Have you been subject to verbal abuze at work in the last month? $93,2 \%$ of the answers were negative, and at the question "Have you been subject to harassment at work in the past year?" almost all the answers were negative, too. $(98,2 \%)$.

\section{Work-life balance and financial security}

This dimension was analyzed based on two indicators, namely: financial security in case of long term sickness and working hours fit in with family or social commitments outside work. Regarding the first indicator, very few people $(17.6 \%)$ responded that they had financial security, and in terms of the second indicator, the majority's belief is that there is a balance between time devoted to work and the time spent with their family.

Tabel 1: Indicators measuring the quality of working life of the Health and well-being dimension

\begin{tabular}{|l|c|c|c|}
\hline & Yes, mainly positively & Yes, mainly negatively & No \\
\hline Work affecting health & $6,5 \%$ & $34,9 \%$ & $58,7 \%$ \\
\hline $\begin{array}{l}\text { Informed about health and } \\
\text { safety risk related to job }\end{array}$ & $91,3 \%$ & $\begin{array}{c}\text { Not very well or not al all well } \\
\text { informed }\end{array}$ \\
\hline
\end{tabular}

Tabel 2: Indicators measuring the quality of working life within the Job fulfilment dimension

\begin{tabular}{|l|c|c|c|c|}
\hline & $\begin{array}{c}\text { Always or most of } \\
\text { the times }\end{array}$ & Sometimes & \multicolumn{2}{|c|}{ Rarely or never } \\
\hline Feeling of doing useful work & $89,1 \%$ & $7,1 \%$ & \multicolumn{2}{|c|}{$3,8 \%$} \\
\hline & Very satisfied & Satisfied & $\begin{array}{c}\text { Not very } \\
\text { satisfied }\end{array}$ & $\begin{array}{c}\text { Not at } \\
\text { all } \\
\text { satisfied }\end{array}$ \\
\hline $\begin{array}{l}\text { Satisfaction with working } \\
\text { conditions in main paid job }\end{array}$ & $12,2 \%$ & $63,2 \%$ & $19,5 \%$ & $5,1 \%$ \\
\hline \multicolumn{2}{|c|}{ Agree } & $\begin{array}{c}\text { Neither agree } \\
\text { nor disagree }\end{array}$ & \multicolumn{2}{|c|}{ Disagree } \\
\hline $\begin{array}{l}\text { Good frieds at work jobisation motivates to } \\
\text { give the best job } \\
\text { performance }\end{array}$ & $75,2 \%$ & $16,4 \%$ & \multicolumn{2}{|c|}{$8,4 \%$} \\
\hline
\end{tabular}


Table 3: Indicators measuring the quality of working life of the Cognitive factors dimension

\begin{tabular}{|l|c|c|c|}
\hline & Almost all of the time & $\begin{array}{c}\text { Between } 1 / 4 \text { an } 3 / 4 \\
\text { of the time }\end{array}$ & Almost never \\
\hline Working with computers & $13,7 \%$ & $10,8 \%$ & $75,6 \%$ \\
\hline European Union (mean) & $29 \%$ & $23 \%$ & $48 \%$ \\
\hline Using Internet or email & $10,6 \%$ & $10 \%$ & $79,4 \%$ \\
\hline European Union (mean) & $22 \%$ & $22 \%$ & $56 \%$ \\
\hline & Yes & \multicolumn{2}{|c|}{ No } \\
\hline Learning Things & $60,3 \%$ & \multicolumn{2}{|c|}{$32 \%$} \\
\hline European Union (mean) & $68 \%$ & \multicolumn{2}{|c|}{$69,6 \%$} \\
\hline $\begin{array}{l}\text { Rotating tasks that } \\
\text { require special skills }\end{array}$ & $30,4 \%$ & \multicolumn{2}{|c|}{$69,6 \%$} \\
\hline European Union (mean) & $34 \%$ & \multicolumn{2}{|c|}{} \\
\hline
\end{tabular}

Tabel 4: Indicators measuring the quality of working life of the Skills, training and career prostects dimension

\begin{tabular}{|l|c|c|c|}
\hline & Yes & \multicolumn{2}{|c|}{ No } \\
\hline $\begin{array}{l}\text { Training in past year paid by } \\
\text { employer }\end{array}$ & $18,2 \%$ & \multicolumn{2}{|c|}{$81,8 \%$} \\
\hline European Union & $34 \%$ & \multicolumn{2}{|c|}{$66 \%$} \\
\hline \multicolumn{1}{|l|}{$\begin{array}{l}\text { Agree } \\
\text { career advancement }\end{array}$} & $\begin{array}{l}\text { Neither agree } \\
\text { nor disagree }\end{array}$ & Disagree \\
\hline
\end{tabular}

\section{Conclusions}

The analysis indicates that there is a pretty solid base for a high quality of life at work, and therefore, the prerequisites for increasing the organizational performance are satisfied. There is only one indicator that raised some problems, namely the one related to the investment in professional development, an aspect which sensitizes not only individuals in the labor market, but also companies' competitiveness.

Currently, the legal framework concerning the competencies and career development, the management of the working conditions and the employees' training, the reconciliation of the life inside and outside of the work place, is mostly harmonized with the regulations of the European Union institutions. Vocational education and training correspond qualitatively and quantitatively to the European values as well as to the Romanian realities of the new economy. Efforts and progress have been made towards a positive trend in the labor income and in the social protection and security policies. [10]

\section{References}

1] Sayyadi H., The quality of work life and organizational commitment. A case study on Education organization staff of Yazd province, Educational Sciences Journal, 1(16), 113132, 2009

[2] Straw, R.J. and C.C. Heckscher QWL: New working relationships in the communication industry. Journal of Labour Studies, 9, 261-74. 1984.

[3] Normala, Daud, Investigating the Relationship between Quality of Work Life and Organizational Commitment amongst Employees in Malaysian Firms”, International Journal of Business and Management. Vol.5 (10), pp. 75-82. 2010. 
[4] Wyatt, T. A. și Wah, C. Y. Perceptions of QWL: A study of Singaporean Employees Development, Research and Practice in Human Resource Management, 9(2), 59-76, 2001, p.60.

[5] Mărginean, Ioan și Marian Vasile (coordonatori) Dicționar de calitatea vieții, Editura Academiei Române, București, 2015, p.51.

[6] Walton, R.E. Criteria for quality of working life. In Davis, L.E., Cherns, A.B. and Associates (Eds.) The quality of working life, the free press, New York: NY. (pp. 91-104), 1975.

[7] Lewis, D., Brazil, K., Krueger, P., Lohfeld, L., si Tjam, E. Extrinsic and intrinsic determinants of quality of work life. Leadership in Health Services, 14, 9-15, 2001.

[8] Walton, R.E Quality of Working Life. What it is? Sloan Management Review XV (1), 11$21,1973$.

[9] Walton, R.E Quality of Working Life. What it is? Sloan Management Review XV (1), 1121, 1973.

[10] www. Eurofound. Europa.eu - Fundația Europeană pentru îmbunătățirea condițiilor de viață și de muncă - Calitatea muncii și a ocupării forței de muncă în românia 